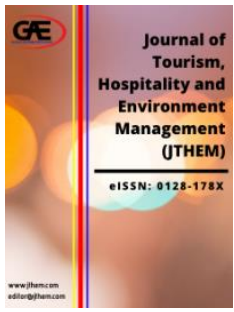

\author{
JOURNAL OF TOURISM, \\ HOSPITALITY AND \\ ENVIRONMENT MANAGEMENT \\ (JTHEM) \\ www.jthem.com
}

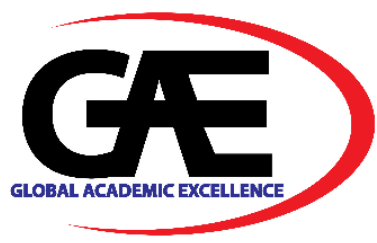

\title{
INADEQUACIES OF LEGAL FRAMEWORK OF MOSQUE TOURISM TOWARDS DEVELOPMENT OF TOURISM INDUSTRY IN MALAYSIA: A REVIEW
}

\author{
Wong Hua Siong ${ }^{1 *}$ \\ 1 Faculty of Law, Multimedia University, Melaka, Malaysia \\ Email: wonghuasiong@yahoo.com \\ Corresponding Author
}

\section{Article Info:}

Article history:

Received date: 10.05.2021

Revised date: 31.05 .2021

Accepted date: 11.06.2021

Published date: 15.06.2021

\section{To cite this document:}

Wong, H. S. (2021). Inadequacies of Legal Framework of Mosque Tourism towards Development of Tourism Industry in Malaysia: A Review. Journal of Tourism, Hospitality and Environment Management, 6 (23), 7178.

DOI: $10.35631 / J T H E M .623008$.

This work is licensed under $\mathrm{CC}$ BY 4.0

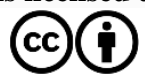

\begin{abstract}
:
Halal or Muslim-friendly tourism is a novel concept in the tourism sector that facilitated new and exciting possibilities for improved financial advancement. Specifically, mosque tourism has become one of the most pertinent areas (an emerging trend under halal tourism) following the rising number of tourists visiting nations with a Muslim-majority population. As such, it was vital to denote the mosque tourism concept and determine subsequent shariah and legal complexities. Additionally, identifying the appropriateness of the laws governing mosque management and visitors proved essential. The current study objectives aim to denote the mosque tourism concept, determine shariah and legal intricacies in mosque tourism, identify visitors' requirements and satisfaction, examine the appropriateness of the laws governing mosque management and tourists, and recommend a legal framework. This qualitative research encompassed a systematic study involving philosophical and academic perspectives with past works of literature. As this study involved library research from different primary data sources, library studies and critical analyses were employed in assessing pertinent materials, data, and knowledge on Islamic religious tourism, particularly Muslim tourist protection concerns. Figures from relevant governmental agencies (Ministry of Tourism and Culture Malaysia) would be duly measured and analysed. Furthermore, assessments of current laws, regulations, and guidelines on tourists' legal protection in mosque tourism were also performed. The anticipated resulted served to recommend the most appropriate legal framework to be incorporated in Malaysia to safeguard all stakeholders' interests in mosque tourism.
\end{abstract}

Keywords:

Inadequacies, Legal Framework, Malaysia, Mosque Tourism 




\section{Introduction}

A mosque or 'masjid' implied a vital function in Muslim societies from the time of the Prophet Muhammad (PBUH) and served as a multifunctional institution for different (political, nonpolitical, and social) reasons, including learning, maintaining justice, settling conflicts, rehabilitating prisoners, and performing marriages and leisure activities (Omer, 2010). In this vein, mosques were inextricably linked to the global advent of Islamic society, culture, and civilisation, including Malaysia. Locally, mosques could be located in almost every town and district in each state. Following the current data from the Department of Islamic Development (JAKIM) website (JAKIM, 2021), the total number of mosques in Malaysia is approximately 6,506. The recent promotion of halal tourism by the Ministry of Tourism Malaysia can also be denoted as mosque tourism (an emerging trend given the rising number of tourists visiting nations with Muslim-majority population).

In 2019, the Sheikh Zayed Grand Mosque in Abu Dhabi recorded approximately 6.6 million tourists and worshippers (879,049 from India, 704,680 from China, 234,849 from Russia, and 193,234 from Germany). On another note, the Al Azar Mosque, Kutubiya, Suleiman Mosque, and Selimiye Mosque became salient examples of historical attractions and spiritual houses that appealed to multiple visitors. Consequently, it was deemed crucial to denote the mosque tourism concept, determine subsequent shariah and legal intricacies, and identify the appropriateness of the laws governing mosque management and visitors. Notably, scholarly literature on Malaysian mosque tourism remained lacking to date, specifically on law-related appropriateness and observations from a legal viewpoint. Given the literary emphasis on halal or Islamic tourism compared to mosque tourism, this study aimed to examine Malaysian mosque tourism and the laws governing the sector.

\section{Literature Review}

Although Malaysia has recently strived to be acknowledged as an Islamic and halal hub, most research on the local Islamic context was confined to halal food and hospitality in hotels. Hence, an examination of the Islamic offerings in Malaysia proved necessary to comprehend self-branding potentials as an Islamic destination for Muslims. Many tangible and intangible Islamic aspects in Malaysia, including mosque and prayer facilities, halal food, Islamic stability, and national safety (Shafaie F, 2015) potentially induced Muslim tourists to visit the country. Essentially, mosques denoted sustainable constructions that were developed to serve Muslim and non-Muslim communities and residents. As mosques implied sources of information and shelter for Muslim and non-Muslim individuals, promoting mosques while acknowledging the Quranic role facilitated non-Muslims to visit the symbolic buildings and comprehend Islam, Islamic rituals, and the followers of Islam (to eliminate the misinterpretation of Islam and Islamophobia). In this regard, mosque tourism implied a strategic and valuable instrument to sustain Islamic tourism (Kessler, 2015).

Malaysia encompasses many old and newly-established and picturesque mosques nationwide with some listed as UNESCO World Heritage sites. The local architectural styles of Malaysian mosques reflected diversity following inspiration from magnificent mosques worldwide, traditional Malay architecture, and local cultures and patterns. Additionally, unique architectural influences symbolised architectural pride (some of the aforementioned influences were oriental, colonial, colloquial, and Moorish). The National Heritage Department (NHD) under the Ministry of Tourism and Culture has executed substantial preservation work on specific historical mosques, such as Ihsaniah Iskandariah (Perak), Mulong (Kelantan), and 


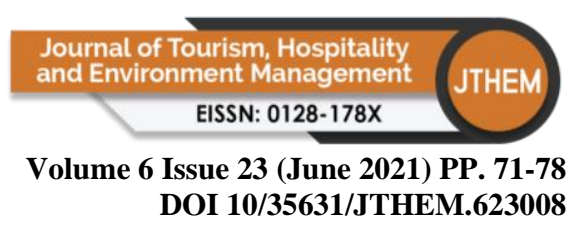

Machap Lama (Melaka). Notably, every mosque reflected distinct attributes that could be catalysed to encourage mosque tourism under spiritual or religious tourism (Abdul Aziz, 2016).

Presently, the local mosques encouraging mosque tourism witnessed an influx of visitors from various Western and Eastern countries. For example, recently-established mosques, including Putra (Putrajaya) and Jamek (Kuala Lumpur) have recorded many tourists from South Korea and China who were inclined to discover the cultural heritage and take vacation selfies (to be posted on social media platforms). The influx reflected the potential for mosque tourism to establish a sound comprehension of Islam and Islamic culture by welcoming non-Muslims to visit mosques (Moghavemi S, 2020). Mosque tourism also demonstrated a novel tourism trend and a potential source of revenue. For example, mosque tourism could provide employment and induce goods and services demands (food and beverage, accommodation, transportation, entertainment, shopping, and tour guides). Subsequently, the requirements would increase tourist expenses in Malaysia and benefit the local economy. In this vein, policymakers and stakeholders should emphasise the mosque tourism market. (Moghavemi S, 2020).

As mosque tourism offered a possibility for mosques and the surrounding local communities to depict moderate and tolerant Islamic teachings practised by Malaysian Muslims, the aforementioned tourism might indicate a means of minimising Islamophobia among nonMuslims for enhanced interaction between Muslims and non-Muslims. As such, Malaysian Muslims were required to conserve the culture and sustain and promote self-identities (Moghavemi S., 2020). The increasing number of Muslim tourists in Malaysia induced an assessment of local branding and marketing approaches as a favoured Islamic destination. Although Malaysia portrayed the attributes of a worthy destination given the multicultural context, cuisine, and heritage, further improvement on Islamic tourism proved necessary (Shafaie F., 2015).

Locally, legal protection for Muslim tourists could be identified in different laws based on the service types. For example, the Consumer Protection Act (CPA) 1999 denotes the primary legislation that safeguards Muslim visitors in Malaysia. As Islamic religious tourism is provided by the tourism sector, the Tourism Industry Act (TIA) 1992 and subsequent regulations are highly pertinent. Although the general law of contract and the tort of negligence are also applicable (services regularly encompassed contractual relationships), the present regulations reflect insufficiency in safeguarding tourists' rights, specifically on Islamic or halal tourism. In this vein, the government needed to affirm that the present regulations are fully enforced with necessary reviews and amendments to address legal loopholes (W Abd Rahman, W.F.I, 2018). Future studies should focus on mosque tourism with efforts to authenticate the term among the Muslim and non-Muslim tourists visiting mosques for religious and cultural reasons. Specifically, future research could emphasise Islamic nations with diverse cultures, histories, and tourism development levels (Kessler, 2015).

Future research development could also emphasise the significant role of mosques (as a cultural catalyst to comprehend Islam through non-Muslim visitors) and clarify the function of concrete religious structures and architecture to highlight experience-based possibilities that potentially conveyed more educational information. As such, scholars and destination planners could extend the current study by examining tourists' requirements and satisfaction involving Malaysian mosques. Essentially, spiritual tourism can only flourish with multiple advantages (spiritual development, inter-cultural comprehension and inter-faith literacy, sustained 


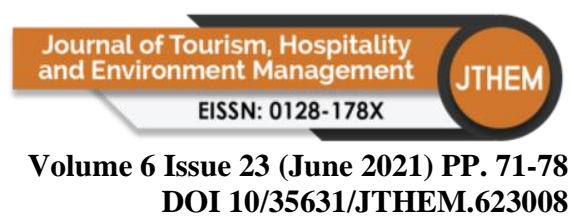

financial growth, and a deep acknowledgement of the rich and diverse spiritual heritage of humanity) through optimal management and the individual thirst for meaning and wisdom (Abdul Aziz, 2016).

\section{Research Objectives}

The study objectives served to denote the mosque tourism concept, determine shariah and legal complexities in mosque tourism, identify tourists' requirements and satisfaction, examine the appropriateness of laws safeguarding mosque management and visitors, and recommend a legal framework.

\section{Research Questions}

The study questions are listed as follows in line with the aforementioned objectives:

1. How to enhance and improve mosque tourism in Malaysia?

2. To what extent are mosque tourists satisfied with mosque management?

3. To what extent are the laws governing mosque tourism in Malaysia adequate in protecting all stakeholders?

\section{Research Methodology}

This qualitative study employed library research and critical analysis to assess pertinent materials, data, and knowledge on Islamic religious tourism, specifically on Muslim tourist protection concerns. The figures were derived from pertinent governmental agencies (Ministry of Tourism and Culture Malaysia) and duly evaluated. Notably, the applied strategy encompassed content analyses of current laws, regulations, and guidelines on tourists' legal protection in halal and mosque tourism.

\section{Data Collection}

The data gathering approaches were categorised into several stages. At the initial stage, a structural work (classified into data observation and questionnaire survey) and in-depth literature review were performed for the research overview. The researchers then examined the position of Malaysian mosque tourism from different viewpoints, such as legal perspectives. The lacuna of legal protection on mosque tourism was duly determined following the literature review. Lastly, the survey questionnaire was developed with all the gathered data.

\section{Data Types}

This research employed primary and secondary data. The primary study data encompassed the statutes, regulations, rules, and guidelines on halal and mosque tourism. Meanwhile, the secondary counterpart involved books, legal documents, and articles from journals and digital resources.

\section{Data Collection Methods}

Two data gathering approaches were employed in this research: library research and fieldwork. The study data for library research were gathered from the International Islamic University Malaysia, Universiti Kebangsaan Malaysia, and Universiti Malaya law libraries. Regarding fieldwork, interviews were performed with relevant participants (tourists, mosque management officers, imams, and religious bodies involving JAKIM, MAIS, MAIWP, and MAIM). 


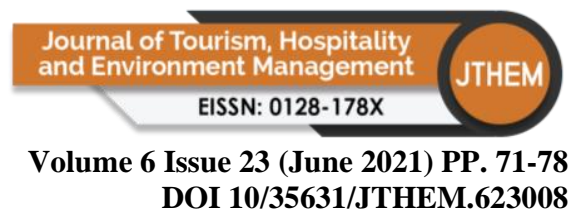

\section{Data Analysis}

Essentially, the primary legal data and secondary data on halal and mosque tourism policies and guidelines were assessed with content analysis. Meanwhile, the interview data were evaluated using thematic analysis.

\section{Discussion}

A total of 4,332,722 tourist arrivals were locally recorded in 2020 (www.tourism.gov.my). Notably, ASEAN nations were ranked as the top contributors of tourist arrivals in Malaysia with 2,868,359 visitors (67.8\%). In this vein, mosques proved to be attractive tourist destinations (although the travel purpose did not involve religion), hence affirming the Malaysian mosque appeal and attractiveness and the need to promote halal tourism. Given the financial downturn caused by Covid-19, mosque tourism denoted a novel trend that potentially created work opportunities. For example, the advent of mosque tourism could induce goods and service-oriented demands (food and beverage, lodging, transportation, entertainment, shopping, and tour guides) that increased tourists' local expenses and significantly benefitted the Malaysian economy.

Essentially, mosque tourism encompassed Muslim and non-Muslim tourists who visited picturesque and historical mosques with exquisite architecture as tourist attractions while travelling (Al Muhsin \& Ahmad, 2020). As such, it was deemed crucial for policymakers and stakeholders to emphasise the mosque tourism market. As mosque tourism encompassed halal tourism (one of the nationally-supported products), mosque tourism development perceivably corresponded to government initiatives. In this vein, halal or Muslim-friendly tourism denoted a novel notion in tourism that facilitated novel and exciting possibilities for improved financial advancement. Specifically, 'halal' implied shariah compliance and human well-being. With mosque tourism as one of the most pertinent areas under halal tourism, the rising number of tourists in Muslim-majority populated nations depicted an emerging trend.

Defining and outlining the mosque tourism concept (one of the most famous tourist activities central to Islamic tourism) should emphasise the sustainable advancement of novel tourist patterns. Additionally, identifying shariah and legal concerns under mosque tourism for optimal roles and functions as a Malaysian tourism destination and tourists' requirements and satisfactions on mosque conditions and management proved essential. As such, it was deemed crucial to identify the appropriateness of the laws governing mosque management and tourists. A clear and absolute legal tool proved necessary to safeguard stakeholders' rights in mosque tourism.

Notably, the Islamic Tourism Centre (ITC) significantly propelled Malaysia towards the forefront of Islamic tourism. The ITC has perpetually collaborated with stakeholders for high Islamic tourism capacities to fulfil Muslim visitors' needs over the years. Additionally, ITC undertook several initiatives to standardise optimal industrial implementations with research, seminars, workshops, and industry outreach programmes and develop local credibility in Islamic tourism. Through ITC, the Tourism, Arts and Culture Ministry outlined three tourism initiatives in 2019 (The Sun Daily) encompassing (but unlimited to) the study of 'sekolah pondok' as an Islamic tourism attraction to elevate mosque tour experiences and acknowledgement of Muslim-friendly hotels. Consequently, the initiatives potentially resulted in optimal Malaysian mosque tourism. 


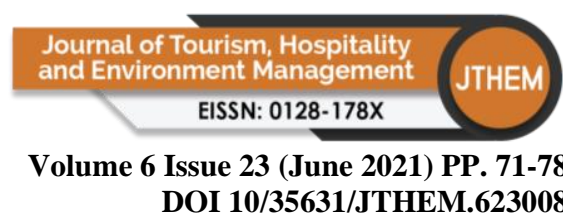

The Halal Industry Master Plan 2030 (HIMP 2030) was established by the Ministry of Economic Affairs to strengthen the socio-economic development of the halal sector. In this vein, HIMP 2030 integrated halal industrial trend and development assessment following specific sectors. The master plan corresponded to the Malaysian halal industry developmental framework and demonstrated possibilities for local socioeconomic advancement to optimise potential financial returns. Scholarly writings involving Malaysian mosque tourism (specifically on the appropriate law and legal viewpoints) remained lacking as most writings generally emphasised halal or Islamic tourism. As such, this study aimed to further examine Malaysian mosque tourism to strengthen Islamic cultural influences on Malaysian heritage and the emerging Islamic tourism market (halal and mosque tourism).

The Consumer Protection Act (CPA) 1999 denotes the primary legislation that safeguards Muslim tourists in Malaysia. Under the tourism sector, Islamic religious tourism and TIA 1992 regulations proved highly pertinent. Additionally, the general law of contract and the tort of negligence are also applicable as the services continuously involved contractual relationships. For example, TIA 1992 potentially encompassed the primary legislation governing the Malaysian tourism sector, such as Islamic religious tourism (Hajj and Umrah services). Nevertheless, the degree to which TIA could provide legal protection to mosque tourism remained ambiguous.

In deterring fraudulent practices among travel agents, TIA decreed mandatory travel agency registrations. Travel agencies operating without a valid license was an offence under Section 5(3) of TIA 1992. The primary aim of travel agency registration involved monitoring agency activities that ensured the protection of consumer interests. Moreover, license holders must be a member of the Malaysian Travel and Tour Association (MATTA) or other relevant counterparts endorsed by the Commissioner of Tourism Industry (Tour Operating Business and Travel Agency Business Regulations 1992), such as the Malaysian Chinese Travel Association (MCTA) and Bumiputra Travel and Tour Agents Association (Bumitra).

As mosque tourists encompassed the industrial services offered to consumers and clients, CPA 1999 also proved to be highly relevant. Dissatisfied customers may complain against tourism service providers. For example, Section 3 of CPA 1999 defined 'services' as the granting of contractual rights, benefits, privileges, or facilities that excluded rights, benefits, or privileges involving the supply of goods or work performance. Specifically, Hajj and Umrah travel agency services were palpably within the section definition. On another note, CPA defined 'consumer' as an individual who (a) acquired or employed services for personal, domestic, or household reasons and consumption and (b) failed to personally acquire or utilise the services for trade resupplies and consumption during the manufacturing process. As such, consumers were not necessarily buyers or contracting parties. Moreover, Part II of CPA (legal provisions that eliminated student victimisation by service providers) managed deceptive conduct, false representations, and unfair implementations.

The Contracts Act 1950 indicates a pertinent statute for contractual issues. Essentially, the regulation offered standard contract-based terms and conditions between travel and tour operators and holidaymakers. For example, Section 17 of the Contracts Act 1950 defined 'fraud' as any act committed to contractually bind another party with misleading statements. Such fraudulent contracts could be voided. In this vein, the Contracts Act 1950 implied another legislation that offered tourists protection against fraud. 




Although travel agencies and agents were professionally obliged (under the duty of care) to conduct the offered services with adequate care and skill, filing cases under the law of negligence proved challenging as the fundamental component of the duty of care (breach of duty and damage) required establishment. As such, the Tribunal for Consumer Claims denoted the primary redress centre in Malaysia that addressed the claims filed by tourists. Meanwhile, the Complaint Management Unit and Community Services under the Ministry of Tourism and Culture Malaysia (to manage and monitor tourist complaints from different communication media) indicated another redress centre where tourists could lodge complaints.

\section{Conclusion}

With the recent increase of mosque tourism-oriented services over the years, this research disclosed several existing laws (ITA, CPA, and Contracts Act) that were applicable in safeguarding Muslim tourists in Malaysia. Following governmental obligations to protect Muslim tourists from potential deception by travel agencies and sustain offered service qualities, the government needed to affirm current law enforcements and review and rectify possible legal loopholes for optimal Muslim tourist protection.

\section{References}

Abdul Aziz, M., Ibrahim, M., Jahnkassim, P.S., Abdullah (2016). Issues and Potential of Mosque as a Spiritual Tourism Destination in Malaysia: Proceeding of ISER $22^{\text {nd }}$ International Conference, Hong Kong, 13th February 2016.

Al Muhsin, M. A., \& Ahmad, N. Z. (2020). The Emergence of Education 4.0 Trends in Teaching Arabic Islamic Finance Curriculum Design: A Case Study. International Journal of Psychosocial Rehabilitation. Vol. 23(4), 1475 - 7192, p.1019 - 1031.

Battour M, Ismaeil MN, Battor M (2011) The Impact of Destination Attributes on Muslim Tourist's Choice. International Journal of Tourism Research 13 (6), 527-540.

Consumer Protection Act 1999.

Contracts Act 1950.

Gan Joo Ee \& Goh Hoon Huar (2014). Hospitality Law, Oxford Fajar Sdn Bhd, Shah Alam

Hotelier Middle East. Sheikh Zayed Grand Mosque saw 6.6 million visitors in 2019. https://www.hoteliermiddleeast.com/business/115414-sheikh-zayed-grand-mosquesaw-66-million-visitors-in-2019. Accessed on 12 May 2021.

Kamarudin L.M, Hairul Nizam, (2013) Islamic Tourism: The Impacts To Malaysia's Tourism Industry, Proceedings of International Conference on Tourism Development, February 2013397.

Kessler, K. (2015). Conceptualizing Mosque Tourism: A Central Feature of Islamic and Religious Tourism. International Journal of Religious Tourism and Pilgrimage, 3 (2), 11-32.

Laderlah SA, Rahman SA, Awang K, Man YC (2011). A study on Islamic Tourism: A Malaysian Experience. $2^{\text {nd }}$ International Conference on Humanities, Historical and Social Science in Singapore, 2011, pp. 184-189. IACSIT Press.

Marzuki A. (2010). Tourism Development in Malaysia. A Review of Federal Government Policies. Theoretical and Empirical Researches in Urban Management. 8(17), 85-97.

Marzuki A. (2009). Impacts of Tourism Development. Anatolia: An International Journal of Tourism and Hospitality Research, 20(2), 450-455.

Moghavemi, S., Sulaiman. A., Taha. A.Z., Abd Shukor M.E. , Mustapha. M.Z., Mohtar. M., Jaafar, N.I, and Zakaria, S.B. (2020). Factors Contributing to Mosque Tourism in 


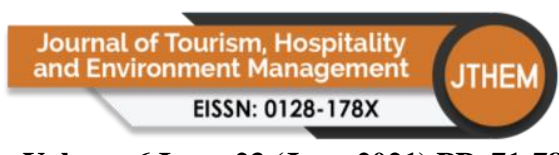

Volume 6 Issue 23 (June 2021) PP. 71-78 DOI 10/35631/JTHEM.623008

Malaysia. A research paper funded by Konsortium Institut Halal IPT Malaysia, University of Malaya MOHE grant MO001-2018.

Mohamad Fazli Sabri (2014). The Development of Consumer Protection Policies in Malaysia, International Journal of Business and Social Research 4(6).

Naemah Amin (2007), Consumer Redress Mechanism in Malaysia: Prospects and Challenges, IIUM Law Journal 15

Nasarudin Abdul Rahman, Naemah Amin \& Haniff Ahamat (2014). The Interface between Competition Law and Consumer Protection: A Malaysian Perspective, Australian Journal of Basic and Applied Science 8(16), 316-323.

Nuraisyah Chua Abdullah \& Zuraidah Mohd Sanusi (2014). Travel Fraud: Comparative Analysis of Regulatory Framework and Legal Redress in Selected Countries, Paper presented at the Proceeding of ICFC.

Nuraisyah Chua Abdullah (2002). General Principle of Malaysian Law (with special reference to the travel and tourism industry), Pusat Penerbitan Universiti (UPENA). Shah Alam

Omer, S. (2010). Some lessons from Prophet Muhammad (SAW) in architecture: The Prophet's Mosque in Madinah. Intellectual Discourse, 18, 115-140.

Rahmah Ismail et al, (2012), A Comparative Study on the Consumer Protection Legislations of Malaysia and Thailand, The Social Science 7(2), 177-188.

Sedigheh M., Ainin S., Azni Z.T., Mohd Edil A.S., Mohd Zulkhairi M., Mozard M., Noor Ismawati J., and Shamshul B.Z. (2020) Factors Contributing to Mosque Tourism in Malaysia. DOI: 10.1007/978-981-33-4854-7_7.

Shafaei, F., Mohamed, B. (2015) Malaysia's Branding As An Islamic Tourism Hub: An assessment. GEOGRAFIA Online TM Malaysia Journal of Society and Space 11 issue 1 (97 - 106).

Tourism Industry Act 1992.

Tourism Industry (Tour Operating Business and Travel Agency Business) Regulations (1992).

W Abd Rahman, W.F.I, Ahamat, H. (2018). Legal Protection of Muslim Tourists in Islamic Religious Tourism in Malaysia: Reality and Challenges. International Journal of Engineering \& Technology, 7 (3.30) (2018) 109-112. 